\title{
Rethinking the Chongqing Negotiations of 1945: Concession-making, the Trust/distrust Paradox, and the Biased Mediator in China's Post-war Transitions*
}

Victor Shiu Chiang Cheng

Australian National University

victor.cheng@anu.edu.au DOI: 10.1163/22127453-BJA10004

\begin{abstract}
This article rethinks what are perhaps the most important attempts at making peace in modern Chinese history: the first post-World War II peace talks convened in Chongqing, between the two old foes of the Chinese Civil War. Previous studies treat the peace conference as a sideshow to the subsequent full-scale civil war. Examining the political and military situation in China toward the end of World War II, this article argues that a peace agreement was needed for both parties. The core of the article examines the hitherto unexplored aspects around the negotiating table: the debate, disagreements and compromises and the American mediator's attempt to alter the dynamics of the peace talks from an inherently biased position.
\end{abstract}

\footnotetext{
* I would like to express my gratitude to Cathryn Game, Larissa Tittl, and two anonymous referees for their comments and suggestions on earlier versions of this article. I am thankful to Anita Chan, Wai Kei Chan, Paul Kenny, Chi Man Kwong, Chi Kong Lai, Jonathan Unger and Haiqing $\mathrm{Yu}$ for their unreserved support. My gratitude also extends to my trainers Chris and Sian, for improving my multitasking skills through circus exercises.
} 
It finds that the history of the Chongqing negotiations is more important to our understanding of China's struggle between peace and war in the modern era than previously acknowledged.

Keywords: Chongqing peace talks, Chinese Civil War, concession-making, biased mediator, Mao Zedong, Chiang Kai-shek

In autumn 1945, China’s eight-year-long war against Japan and World War II (WWII) had barely ended. At this point, the race for territorial recovery after the Japanese surrender between the two opposing Chinese sides - the Chinese Communist Party (CCP) led by Mao Zedong and the Chinese Nationalist Party (Kuomintang, [KMT]) government headed by Chiang Kai-shek — was about to trigger a new round of civil war in China. To avert this, Mao and his men from their headquarters in Yan'an were invited to attend the highly anticipated peace talks with Mao's arch rival Chiang, and top-ranking KMT officials, in the KMT wartime capital Chongqing in late August. Mao's visit to Chongqing marked the beginning of a summit sponsored by the United States of America's (US) government. Otherwise known as the Chongqing negotiations, it was the first post-WWII attempt at peace for these two traditional opponents from the Chinese Civil War. The two belligerent parties reached an interim peace accord in October 1945, but this initial progress at the negotiating table failed to prevent the subsequent full-blown civil war (1946 to 1949), which shaped the political landscape of East Asia for the next seven decades.

The final outcome of the Chinese Civil War seems to support a view that the Chongqing negotiations were meaningless. ${ }^{1}$ As Yu remarks, both parties simply went "for a reluctant and pretentious peace talk." ${ }^{2}$ Some believe that the leaders of both camps were

\footnotetext{
${ }^{1}$ Clubb 1972, 260; White and Jacoby 1961, 288.

${ }^{2}$ Yu 1996, 240.
} 
pressured to prioritize military options; this implies that war became the dominant theme and that negotiations were of secondary importance. ${ }^{3}$ Others have simply declared the negotiations overrated, arguing they do not deserve historical prominence. ${ }^{4}$ The focus of this paper, however, is not the two belligerent parties' initial intent to enter talks, but the interaction dynamics over the negotiating table that shaped the negotiation process of the Chongqing peace talks.

It is a matter of record that the fragile agreement of Chongqing was part of a failed attempt at peace. The results speak for themselves: a full-scale civil war in China that fed into the rivalry between Cold War superpowers. The negotiation process of these failed peace talks, not unexpectedly, has attracted very little scholarly interest and remains a largely unexplored topic. This contrasts sharply with research into the Chinese Civil War's battle engagements, which attract enormous interest. ${ }^{5}$ However, peace negotiations and war are often two sides of the same coin. World War I, for instance, was "a diplomatically botched negotiation," as American diplomat Richard Holbrooke has said. ${ }^{6}$ If the combat operation process of the Chinese Civil War requires in-depth analysis, it seems reasonable to ask if there was more to this historic peace conference than its outcome.

This paper contends that the history of the Chongqing negotiations, although they lasted only six weeks, is more significant to understanding China's post-war struggle between peace and war than previously thought. It studies the debates, disagreements and compromises of

\footnotetext{
${ }^{3}$ Lew 2009, 19; Wang 2002, 14-42.

${ }^{4}$ Deng 2005, 30-64.

${ }^{5}$ See for example, Tanner, 2013; Tanner, 2015.

${ }^{6}$ Quoted in Bingley 2015, 67.
} 
the negotiations that were shaped by the interactions between the two traditional civil war rivals in the peace talks. It begins with a brief overview of the intertwined history of the two parties' civil strife, peace initiatives, and their fragile anti-Japanese alliance, from the late 1930s through to the end of WWII, until the two antagonists engaged in comprehensive peace talks against the backdrop of changing domestic and international environments. It finds that, while the two parties fought each other fiercely on the battlefield, they adopted unsystematic piecemeal solutions to prevent the armed conflict from spreading and the complete breakdown of their wartime cooperation. Although the post-WWII race for territorial recovery between the two triggered a new bout of civil war in China, this study shows that a peace deal was needed for both parties in the post-war environment. Therefore, the real challenge for the two belligerent sides and their American mediator during the peace talks in Chongqing was not securing peace in China once and for all. Rather, it was whether they could pick up where the two parties had left their awkward wartime alliance.

The US government, which was inherently biased toward Chiang's government, facilitated the peace conference. However, its mediator, Ambassador Patrick J. Hurley, was not directly involved in the peace talks but only intervened when the negotiation was verging on breakdown. This study shows how the biased US mediator altered the peace talk dynamics and impelled both Mao and Chiang to adopt a more integrative approach in their respective concession-making strategies. The article highlights the ongoing interactions at the negotiating table that forced the two warring parties to face peaceful alternatives. The peaceful option was only a temporary measure at the time, and both parties did not follow through with plans to develop it into a more robust solution. This nevertheless confirms that the negotiations were instrumental in promoting possible creative alternatives to war. 
This article reviews the original negotiation meeting conversation records documented and approved by the KMT and the CCP. ${ }^{7}$ Despite the complete set of conversation records ${ }^{8}$ or synopses ${ }^{9}$ of these meetings being published, an enormous wealth of knowledge about peace-making locked within the records remains relatively unexplored. In particular, the significance of some of the creative ideas proposed by the negotiators to break impasses was not recognized until decades later. Clearly, these ideas need to be understood by a contemporary mind.

Fortunately, some of the negotiation concepts within these records have been mentioned in the discussed topics on media outlets with their modern names (e.g., high ball tactics and third-party intervention) thanks to the extensive, global use of negotiation and mediation as alternatives to litigation. This article examines the hidden wisdom in these historical records through the microscope of modern negotiation and mediation literature. This literature provides a conceptual basis for the historical inquiry of this paper, given that negotiation and mediation have never been specialized knowledge intended only for a small group of political scientists, mathematicians and game theorists. ${ }^{10}$

At present, the two opposing yet well-armed governments rule independently: one on the mainland as the People's Republic of China (PRC) and one in Taiwan as the Republic of China (ROC). This has been the situation since the KMT fled to Taiwan in 1949 after its

\footnotetext{
${ }^{7}$ Qin 1981-88, series 7, vol. 2, 60, 68; Zhonggong zhongyang wenxian yanjiushi 1989, 621. ${ }^{8}$ Qin 1981-88, series 7, vol. 2, 45-97; Zhang 1968, 134-45.

${ }^{9}$ Zhonggong Chongqing shiwei dangshi gongzuo weiyuanhui et al., 1984, 189-228.

10 This paper cites conceptual studies on negotiation from authors who acquired expertise on resolving conflict in a variety of areas, including business, legal and anthropology.
} 
defeat by the mainland CCP. However, tension has been kept to a low level in recent years. Under the circumstances, the history of the Chongqing negotiations, notwithstanding its lack of scholarly interest, can still capture attention, not only in the Chinese language media but also in international news.

In 2015, the presidents of the two historical antagonists met for the first time in the seven decades since Mao and Chiang's last summit at the Chongqing negotiations in 1945. Although the conference was held at a third-party venue in Singapore and achieved nothing concrete, reporters have declined to judge the meeting by its outcome. A correspondent has connected the meeting with the peace summit of 1945 between Mao and Chiang. Such a view virtually aligns the current summit and the historic Mao-Chiang meeting along a continuum. $^{11}$

In China, the historic peace conference has inspired an upcoming television drama series, Chongqing Negotiations (Chongqing tanpan 重庆谈判), scheduled for a 2019 release on China Central Television. This new drama is preceded by the 1993 movie of the same name produced by Changchun Film Studio. A book published in PRC in 2002 for a general readership even considers the Chongqing negotiations as one of the most significant events in twentieth-century China. ${ }^{12}$ The quality of media coverage shows that the historic summit still has the power to capture the public imagination.

\footnotetext{
${ }^{1}$ Philips, 2015.

12 Wang and Tu, 2002, 207-12.
} 
In view of the gap between academic studies and media exposure, and recent developments in the uneasy cross-strait rapprochement, this article highlights this short but significant history of peace-making attempts in China's post-war transitions.

\section{An Awkward Alliance}

During his stay in Chongqing, Mao sent his negotiators to attend most official meetings while he stayed aloof from the grueling negotiations held behind closed doors. Except for holding private talks with Chiang, Mao maintained appearances on most public occasions. He endeavored to lobby senior government officials, leaders of the minor parties and nonpartisans in personal talks and informal meetings. ${ }^{13}$

In late September 1945, when negotiations had already passed the halfway mark, one of the minor party leaders, Jiang Yuntian, was invited for a private talk with Mao. When the pair met, Mao revealed that the negotiations had so far been disappointing: disagreements on the armed forces ratio of the two rival armies and the authority of CCP-held areas had created an impasse. Although a private meeting with Mao might have been a godsend to Jiang, he did not treat Mao with adulation. On the contrary, Jiang unreservedly criticized the political ethics of the two major parties, including their relentless pursuit of military power and carving up of territories for self-serving purposes. For Jiang, this wheeling and dealing was merely delaying the inevitable. ${ }^{14}$

Throughout the meeting, Jiang Yuntian created some embarrassing moments that Mao found difficult to ignore, despite his clever quips and buffoonery. On one occasion, Jiang asked Mao if he would relinquish military power in favor of a democratic political system

\footnotetext{
${ }^{13}$ Zhonggong Chongqing shiwei dangshi gongzuo weiyuanhui et al., eds. 1984, 91-132.

14 Jiang 1976, 1-2.
} 
akin to the West. Mao did not respond directly, instead replying "Just think that if I can rely solely on my political skills to assume power, why do I have to bear the financial burden of maintaining hundreds of thousands of troops?"15

Mao's response to Jiang Yuntian's query provides a critical reflection on the relationship between the KMT and the $\mathrm{CCP}$, which had been based on talking peace and making war since the 1920s. Previous research has been devoted to the military conflict between the two parties: the civil war from 1927 to 1936, the simultaneous internal strife amid their wartime alliance against Japan, and the CCP's military and base (Liberated Areas) expansion during the war with Japan from 1937 to $1945 .{ }^{16}$

However, little attention has been paid to each party's efforts to reduce tension. In particular, the survival of their awkward wartime united front from 1937 to 1945 has been considered as either a miracle or a patriotic act. ${ }^{17}$ Existing historical records show that there was no miracle: In an attempt to avoid a split, high-level officials, negotiators and army officers from both parties engaged in countless negotiations and side conversations. These negotiations were tough because the major differences between the two parties on issues including political ideologies, the autonomy and expansion of the CCP's Liberated Areas, and the armed forces, were too significant for a comprehensive resolution. ${ }^{18}$

\footnotetext{
${ }^{15}$ Jiang 1976, 1-2, 4.

${ }^{16}$ See for example, Wei 1985; Benton 1999; Lai 2011; Van de Ven 2017.

${ }^{17} \mathrm{Wu} 1992,98-103$.

18 Yang 2005, 110-63; Yang 1992, 78-114; Qin 1981-88, series 5, vol. 1, 432-502, vol. 2,
} 55-199, vol. 3, 9-49. 
From 1937 to 1943, both parties had proposed a range of local stop-gap arrangements either to defer the crisis or stop the fighting from spreading. These temporary measures included sending a civilian commissioner (Zhuanyuan 专员) to the key conflict zone, ${ }^{19}$ separating the two forces via demarcation of war zones on a case-by-case basis, ${ }^{20}$ the redeployment of troops, ${ }^{21}$ and promoting bilateral liaison between the parties. ${ }^{2}$ Many of these creative conflict management approaches were either partially or not implemented. However, as Wise argues, the principles and concepts from previously failed plans became the precedents for subsequent negotiations. ${ }^{23}$

In other words, the two disputed parties had been negotiating to cut a large and complex issue into smaller and more manageable units at a time when a comprehensive resolution of their ongoing conflict was still remote. While the "fractionating" ${ }^{24}$ approach made both parties focus on small and separate issues rather than their major differences, it helped China avert a full-blown civil war during its conflict with Japan. As long as the leaders of the two parties still believed a weak united front was better than a total split, China

19 Yang 2005, 205-9.

${ }^{2}$ Xiao 1987, 264-66; Zhonggong zhongyang wenxian yanjiushi 2006, 956.

${ }^{21}$ Liu, 1986.

${ }^{22}$ Shi and Zhen, 1987.

${ }^{2}{ }^{3}$ Wise 2018, 31-32. Wise's report was written for the Political Settlement Research Programme run by a consortium of seven peace, justice and conflict resolution organizations and universities in Europe and Africa. The report is based on PA-X - a peace agreements database from 1990 to end of 2019. PA-X is an output of the Political Settlement Research Programme.

${ }^{24}$ Fisher, 1964. 
lived to fight another day. In the end, China achieved a bitter victory over Japan amid a conflict-laden KMT-CCP wartime cooperation.

The US - China's major wartime aid program provider and the most important ally of the KMT government — was increasingly apprehensive about the negative impact of infighting on China's war effort. As a result, the US offered to facilitate a comprehensive reconciliation between the two parties. ${ }^{25}$ The US intervention, however, resulted in futile mediation attempts in late 1944 by Patrick J. Hurley, the presidential emissary and later the US ambassador to China. A crucial part of the US government's action plan was to sustain Chiang's rule. ${ }^{26}$ From the CCP's perspective, this approach rendered Hurley a biased mediator. For the CCP, the US was a capitalistic country, one that would recognize the KMT as the only legitimate government of China. ${ }^{27}$

As one of the main purposes of Hurley's mission was "to unify all the military forces in China" against Japan, ${ }^{28}$ his mediation approach was fairly ambitious. It forced the leaders of both parties to square-off over the most contentious issues in their relationship—such as political power sharing and the command of troops - where the room for concessions had been very narrow. ${ }^{29}$ It is therefore not unexpected that the US-brokered negotiation was

${ }^{25}$ Cable, Hull to Gauss, 14 July, in FRUS, 1944, vol. 6, 245.

${ }^{26}$ Hurley to Roosevelt, 10 October, FRUS, 1944, vol. 6, 166-70.

${ }^{7}$ Chen to Vincent, 24 January, Hurley to Stettinius, 19 February, FRUS, 1945, vol. 7, 185, 234-36.

${ }^{2}$ United States Department of State 1967, vol. 1, 71.

${ }^{29}$ Hsü 1990, 605-6. 
deadlocked from the outset before it broke off in February $1945 .{ }^{30}$ Hence, when the Japanese surrendered on August 15, 1945, the hostile negotiation situation meant that neither party was able to resolve their issues, with the surrender exacerbating the difficulties.

Japan's surrender rekindled the civil war between the CCP and the KMT, as both parties asserted the right to claim Japanese-occupied territories in China. Making use of their enhanced military might, the CCP intensified the campaign for territorial expansion in order to achieve a satisfactory post-war settlement. ${ }^{31}$ The bulk of the KMT forces, on the contrary, were still deployed in south-west China in the immediate aftermath of the war. They were placed at a significant disadvantage in the race for territorial recovery against the $\mathrm{CCP}$, which was based in rural areas close to Japanese-controlled territories in eastern and northern China - the nation's political and economic center.

Military uncertainty created chaos. Some KMT-aligned militia groups had entered the Japanese-occupied areas without prior authorization from Chiang's government. The unauthorized troop movement by the two opposing Chinese parties prompted the Japanese to register a complaint with the Supreme Commander of the Allied Powers, Douglas MacArthur, stating that forces from both Yan'an and Chongqing had created confusion. This meant that the Japanese armies had difficulty surrendering according to the terms and conditions stipulated in the Potsdam Declaration. The Japanese complaint was made against both parties, but the embarrassment of receiving a complaint from a defeated nation was

\footnotetext{
30 Yang 2005, 269-94.

${ }^{31}$ Cheng 2005, 76.
} 
reserved for Chiang's regime. ${ }^{32}$ The KMT was losing the race for territorial recovery, even on paper. Not surprisingly, Chiang tried to persuade Mao to visit Chongqing and settle their differences via negotiation.

Chiang sent three consecutive invitations to Mao for a summit meeting. Mao finally agreed on August 24, 1945. ${ }^{3}$ Some believe that Mao accepted Chiang's invitation because of foreign pressure, particularly advice from Stalin. ${ }^{34}$ Others contend that Mao met Chiang mainly because of domestic considerations and that he was more concerned about US, rather than Soviet, attitudes. ${ }^{35}$ Mao, however, admitted that he agreed to negotiate due to all major powers disapproving of a civil war in China. ${ }^{36}$

Foreign pressure might have had an impact on Mao's decision-making, but the growing dilemma of the CCP's military strategy toward the end of WWII was also a contributing factor that prompted Mao to seek a modus vivendi with Chiang. Mao and his interlocutors soon discovered that it was anti-war sentiment, rather than the communist revolution, which was gaining most public support in post-war China. ${ }^{37}$ For instance, the CCP's forceconcentrated offensives against the KMT armies were subject to local resentment even before

32 Jiang Zhongzheng zongtong wenwu (22 August 1945), Guoshiguan, 002-020300-00027038; CKSD, 22 August 1945, Folder 9, Box 44.

${ }^{3}$ Qin 1981-88, series 7, vol. 2, 23-29.

${ }^{4}$ Sheng 1997, 103-04; Heinzig 2004, 64-73.

${ }^{3}{ }^{\mathrm{Hu}} 2003,397-98$.

${ }^{3} 6$ Mao 1961A.

37 Zhou 1996, 3-4, 9. 
the Japanese surrender. Force concentration was important to Mao's guerrilla army to win significant battles against the KMT. While a guerrilla army may concentrate large forces for a specific operation, the concentrated guerrilla units should disperse swiftly upon completion of an operation. ${ }^{38}$ The CCP's case nevertheless shows that once battles intensified, there was no guarantee of how soon the fighting would end; the concentrated army units had to seize food from peasants within the warring lands to replenish the armies' dwindling food supplies.

In a large-scale military conflict against the KMT in the eastern coastal province of Zhejiang, which took place just months before the Japanese surrender, the CCP amassed an army of nearly twenty thousand men in an area that extended over 250 square kilometers at the Tianmu Mountain (approximately 80 kilometers west of Hangzhou). The combat lasted for five months from February to June 1945, but the local peasant economy was ruined in the first three months of fighting. In the campaign's final stage, the food source of the poorest farm laborers was wiped out completely after they gave ceded to the CCP troops' extortion demands. A report written by the campaign's CCP commander reveals that the depredation caused by food seizures had a profound negative impact on the civil population, dealing a gargantuan blow to the mass-based revolution for communism. ${ }^{39}$ After WWII, even the CCP's sympathizers found its continued military campaigns hard to justify. ${ }^{4} 0$

38 United States Department of the Army 2009, 87.

${ }^{3}$ Cable, Su Yu to Central Committee of the CCP, 18 April 1948, in Zhonggong Kaifeng shiwei dangwei bangongshi and Zhonggong Shangqiu diwei dangwei bangongshi 1988, 3135.

40 Zhou 1996, 9. 
Additionally, the CCP's preferred guerrilla tactic of sabotaging railroad lines was now facing possible local resistance. The KMT hailed the restoration of commuter rail services as a priority policy ${ }^{4}{ }^{1}$ and vehemently criticized the CCP's guerrilla-style railway sabotage operations, which deprived locals of their right to return to their pre-war homes. ${ }^{42}$ Mao subsequently urged his commanders to give away the dismantled railway timber sleepers and metal parts to the locals, hoping this tactic would result in a reduced public backlash against his troops. ${ }^{4}{ }^{3}$ However, Mao's policy did little to win over frustrated middle-class city dwellers, who opposed the CCP's hit-and-run operations aimed at transport links. ${ }^{44}$

The operations of CCP forces in 1945 show that a peace deal was needed for the Chinese communists: Mao did not simply go to Chongqing on Stalin's order to humor the Americans. This conflicts with two popular arguments advanced by previous studies. First, it has been argued that the post-war KMT-CCP negotiations resulted from a false hope for peace. ${ }^{45}$ Second, it is believed that the CCP's short-term tactical maneuvers in handling the

${ }^{4}$ Cable, Du Yuming to Chiang Kai-shek, 25 November 1945, in JZZD, vol. 63, 645-46.

42 Cable, Fu Zuoyi to Mao Zedong, in Zhongyang ribao, 26 October 1945.

${ }^{43}$ Cables, Mao to Chen Yi and Li Yu, cc. Central China Bureau, 30 October 1945, Mao to Xiao Ke and Luo Ruiqing, 10 November 1945, Mao to Li Yunchang and Sa Ke, 14 November 1945, in Zhonggong zhongyang wenxian yanjiushi and Zhongguo renmin jiefangjun junshi kexue yuan 1993, vol. 3, 97-98, 128-29, 139-40.

${ }^{4} 4$ Zhou 1996, 9.

${ }^{4} 5$ Tsou 1963, 404. 
US's third-party intervention in the KMT-CCP conflicts were central to the history of this period. ${ }^{46}$

\section{The Stalemate}

Shortly after Mao agreed to meet Chiang, he wrote a carefully worded letter to Albert

C. Wedemeyer, commander of the US Force in China and Chief of Staff to Chiang. Wedemeyer and his team provided military intelligence analysis in support of the US Embassy in China, but were not involved in Hurley's mediation between the CCP and KMT. ${ }^{4}$ As Wedemeyer played no part in the negotiations, Mao's letter was written in reply to Ambassador Hurley's request to visit Yan'an. It essentially demanded that Hurley come to Yan'an and escort Mao to Chongqing in the same plane. ${ }^{48}$ Mao might not have been worried that Chiang's secret agents would assassinate him mid-air, as Chang and Halliday have suggested. ${ }^{49}$ But Mao's assurance-seeking from the Americans (who were biased toward the Nationalists) regarding his safety in Chongqing shows the advantage a partial peace-broker possesses over the least favored side in peace negotiations. ${ }^{50}$ In the CCP's case, the US unquestionably sided with the KMT. Mao certainly would not have treated Hurley as an ally,

${ }^{4} 6$ Sheng 1997, 120.

${ }^{47}$ Cable, Hurley to Byrnes, 9 June, in FRUS, 1945, vol. 7, 406-10; Wedemeyer 1958, 34546.

48 Zhonggong zhongyang wenxian yanjiushi 1993, vol. 3, 13.

${ }^{4}$ Chang and Halliday 2005, 296.

${ }^{50}$ Corbetta and Melin 2018, 2209. 
but the American had more leverage (e.g., in the form of military aid) over Chiang and was less likely to misrepresent the intention of "their side."

Accompanied by Hurley and the KMT negotiator Zhang Zhizhong, Mao and his party arrived at Chongqing on August 28, 1945 on a US military aircraft. ${ }^{5}$ Such an arrangement further confirmed the American's role as the negotiation's facilitator; in particular, Hurley's position as a mediator. Hurley adjusted his approach as soon as the negotiations commenced. He acted as a passive peacemaker and allowed the negotiators from both parties to enter direct talks. While being a respectful third party for most of the negotiations, both parties apprised the American of the talks' progress. ${ }^{52}$ As the analysis of this article unfolds and reveals, Hurley was not sent to China to only collect and provide information.

The peace talks took place on two levels. One level comprised summit meetings in which Chiang and Mao met in face-to-face discussions. Chiang and Mao met on no fewer than ten occasions during the latter's visit, but only six were private discussions. The rest of the meetings consisted of informal discussions during social functions, courtesy calls, and photo opportunities. ${ }^{53}$ At another level, the most effective representatives from each party held rounds of negotiations behind closed doors.

Chiang dispatched a team of four to lead the negotiations. They were Zhang Qun, Wang Shijie, Zhang Zhizhong, and Shao Lizi. While all four were prominent members of the

\footnotetext{
51 Xinhua ribao, 29 August 1945.

52 "The Chinese Ministry of Information to the American Embassy." 2-3 September and document, Zhou to Hurley, 16 September, in FRUS, 1945, vol. 7, 455-65.

5 s JZZD, vol. 62, 363-744, vol. 63, 2-123.
} 
KMT, Zhang Qun was also a strong supporter and loyal friend of Chiang. ${ }^{5}$ Wang, Shao, and Zhang Zhizhong had been regular participants in the two-party peace talks. Ultimately, Foreign Minister Wang attended only the pre-negotiation discussions, leaving for an overseas diplomatic assignment just before formal negotiations began. ${ }^{5}$

Mao sent his deputy Zhou Enlai as chief negotiator. Zhou's role was supported by Wang Ruofei. Wang had been negotiating with the Nationalists in Chongqing with Zhou since 1944. Wang was once arrested, ferociously interrogated by Chiang's secret agents, and imprisoned for more than five years at notorious KMT prisons. During his trials and imprisonment, Wang stubbornly resisted authority even when threatened at gunpoint. Wang's uncompromising stance toward the Nationalist law enforcers was feted by his fellow inmates. ${ }^{56}$ When he applied the same attitude at the peace talks, it caused some trouble for Zhou.

Although Chiang and Mao sent experienced negotiators to set the stage for bargaining, both parties held firm, showing no sign of making early concessions. Chiang, who was keen to recover lost ground in his race for territorial recovery against the $\mathrm{CCP}$, intended to play tough, particularly on military issues. ${ }^{57}$ Mao, on the other hand, unveiled his negotiation policy to his comrades before departing for Chongqing. He even indicated that he was prepared to make negotiation trade-offs with the KMT. ${ }^{58}$ However, as Mao had stepped up

\footnotetext{
54 “Annex,” Wallace to Roosevelt, 10 July, FRUS, 1944, vol. 6, 240-44.

${ }^{5}$ Wang's diaries, 28 August and 4 September 1945, in Wang 1990, 161, 168-69.

${ }^{5}$ Chen and He 1986, 112-58, 257-63.

${ }^{5}$ CKSD, 20 August 1945, Folder 9, Box 44.

${ }^{5}$ Mao 1961A, 49.
} 
his war talks against the KMT toward the end of the war, he was in no mood to ingratiate himself with Chiang. ${ }^{59}$

The CCP interlocutors took the initiative and, in the meeting held on September 3, 1945 made a rather aggressive opening bid. ${ }^{6} 0$ Two extremely controversial and divisive topics existed within the proposal. On issues concerning the post-war army reorganization, they demanded that the $\mathrm{CCP}$ retained an army of forty-eight divisions. In seeking recognition of the Liberated Areas, they presented the KMT with a fait accompli. Zhou and Wang requested that CCP officials be appointed, among other crucial local government positions, as the administrative heads of five major provinces in North China on the grounds that they had already seized an unassailable position in these provinces. ${ }^{6}{ }^{1}$ In political settlement parlance, the CCP considered territorial power-sharing (e.g., delegation of a central government's power to local groups who declare rule of a particular geographical area) as one of its preferred mechanisms for resolving conflict, which should be negotiated for the provisions of the forthcoming peace accord. ${ }^{6}{ }^{2}$

The danger of the fait accompli tactic is that it might push the opponent's loss aversion to an extreme position. ${ }^{6}$ From the CCP's perspective, however, Zhou merely presented

${ }^{5}$ Mao, 1961B.

60 Wang's diary, 3 September 1945, in Wang 1990, 164.

61 "Chinese Ministry of Information to the American Embassy." 3 September, in FRUS, 1945, vol.7, 457-59; Qin 1981-88, series 7, vol. 2, 39-41, 45-55.

${ }^{6}$ Svensson 2009, 464-65; Wise 2018, 1.

63 Jervis 1989, 170. 
indisputable facts to the Nationalists. ${ }^{6}{ }^{4}$ Seething with rage after discovering Zhou's proposal, Chiang threatened to make it publicly available. That move would certainly have derailed the negotiation before it had started, but Chiang soon changed his mind after seeking counsel from his negotiators. ${ }^{6}$ However, he did not stop Wang Shijie from writing a personal letter to Mao, pleading for a compromise. ${ }^{6} 6$

According to some scholarship, acknowledging and engaging with the pre-existing territorial claims of local armed groups is a useful tool for risk mitigation in peace negotiations. This is because a non-state actor may think it unnecessary to negotiate with a central government over the issue, as it would already have established de facto control over the territories. ${ }^{6}{ }^{7}$

However, Chiang did not view Zhou's extreme claims as a compromise mechanism that would resolve the peace talk's central sticking points. Chiang's negotiators rejected Zhou's two major demands outright, claiming that the Liberated Areas were now irrelevant and that the maximum number of CCP armed forces divisions to which the government could give consent was twelve. ${ }^{6}$ From September 4 to 11, 1945, the negotiators engaged in four feisty

${ }^{6}$ Deng, 2006.

${ }^{6}$ CKSD, 4 September 1945, Folder 10, Box 44.

66 Wang's diary, 4 September 1945, in Wang 1990, 168-69.

67 Wise 2018, 5, 29.

68 "Chinese Ministry of Information to the American Embassy." 3 September, in FRUS, 1945, vol.7, 459-62. 
debates, but failed to make headway in ending the military standoff. 69 The CCP negotiators called for a rational and equitable reorganization of all armed forces nationwide, and they were firm on their forty-eight division demand. The KMT representatives argued that this number was excessive for a standing regular army in peace time. They insisted that their twelve-division offer was the best the CCP could obtain. ${ }^{70}$ Chiang and Mao therefore needed to resolve the stalemate face to face.

\section{The Game Changer}

Chiang and Mao held a constructive meeting on September 12. Mao promised a further reduction of his army to twenty-eight divisions. ${ }^{71}$ The offer was by far the biggest concession since the negotiations had begun. Mao's abrupt reversal of his position might have been surprising, but it can be viewed as a strategic concession to break the impasse.

First, Mao did not specify how long it would take to reduce his armies to the number he proposed. Given the size of the CCP military, Mao could have been discussing a topic for the distant future. Second, the CCP regular forces could be used as fully fledged guerrillas operating in small units, thanks to their outstanding deployment capabilities. Conversely, the CCP guerrilla teams could conduct regular or mobile warfare after proper force concentration

\footnotetext{
${ }^{6} 9$ Qin 1981-88, series 7, vol. 2, 45-73; Zhonggong Chongqing shiwei dangshi gongzuo weiyuanhui et al., 1984, 191-204.

70 "Chinese Ministry of Information to the American Embassy." 3 September, in FRUS, 1945, vol.7, 457-59, 459-62.

${ }^{71}$ CKSD, 12 September 1945, Folder 10, Box 44.
} 
and enhancement in both organization and weaponry. ${ }^{72}$ Once these forces played havoc with the Nationalists, their whereabouts and exact numbers would be undetectable, let alone subject to decommissioning. Mao could have reduced the official numbers in his regular armies without reducing the actual quantity of his troops.

Of course, even the smallest change in force deployment would affect Mao's military strategy, but this could not possibly outweigh the benefits for his negotiation game plan. For Mao, the official figures of active army divisions and the actual number of troops in an army unit were different things. No matter how he decided to organize them, he would not give them away easily. "The arms of the people, every gun and every bullet, must all be kept, must not be handed over," Mao emphasized. ${ }^{73}$

The actual number of the CCP forces is interesting. The CCP representatives started the negotiations claiming they had a regular force of 1,200,000 men (more than eighty army divisions), using this to support their demand to retain at least forty-eight divisions. ${ }^{74}$ Historical evidence, however, shows that the CCP leaders had different versions of the account regarding the actual number of their armed forces.

A CCP Central Committee (CC) directive in July 1944 stated that it had only 470,000 regular (fewer than forty army divisions) and 2,100,000 militia troops. Notably, the same directive stated specifically that the current policy of army streamlining was still in force.

\footnotetext{
72 Cheng 2005, 74-75.

${ }^{3}$ Mao 1961C, 57.

${ }^{74}$ Qin, 1981-88, series 7, vol. 2, 51; Zhonggong Chongqing shiwei dangshi gongzuo weiyuanhui et al., 1984, 191-96.
} 
Regional commanders were instructed to maintain the existing size of the regular army for one year before considering any aggressive army expansion program. ${ }^{75}$ Astonishingly, when the CCP leaders negotiated with the Americans in a bid to obtain US arms in December 1944, they claimed they had an army of 650,000 men and a militia force of $2,500,000$ combatants. ${ }^{76}$ In September 1945, the CCP negotiators required statistical data to support their claim of a one-million-plus army. Their comrades in Yan'an passed on the numbers they needed - the CCP had a staggering 1,270,000 regular troops. ${ }^{77}$

For the KMT, the figures provided by the CCP were palpably spurious. According to the statistical figures provided by the KMT Board of Military Operation (junlingbu 军令部) on February 20, 1945, the CCP had a standing army of 619,800 men, out of which only 434,780 were properly trained and organized. ${ }^{78}$ Therefore, from the KMT's perspective, the CCP was using a "highball" negotiation tactic ${ }^{79}$ — an outrageous bid that was impossible to justify — and they questioned the validity of the CCP's claim from the start. Zhang Zhizhong queried, "How it is possible that your army expands so quickly?" 80 Questions of this kind put Zhou and Wang Ruofei on the spot, and they tried to avoid discussion of issues related to

${ }^{5}$ CC directive, recipient unavailable, 1 July 1944, in Zhongyang dang'anguan 1989-92, vol. $14,261-67$.

76 Yu 1996, 186-87.

77 Yang 1992, 214.

${ }^{78}$ Qin 1981-88, series 5, vol. 4, 429-30.

79 Lewicki et al., 2010, 61-69.

80 Qin 1981-88, series 7, vol. 2, 57; Zhonggong Chongqing shiwei dangshi gongzuo weiyuanhui et al., 1984, 196-201. 
their forces' complement. It would have been awfully embarrassing for them if they were forced to clarify that the CCP had not incorporated the surrendered Japanese puppet troops (i.e., the Collaborationist "Chinese" Army) into its ever-expanding army. ${ }^{81}$ As in September 1945, Yan'an initiated a new round of army expansion. The mobilization of Japanese puppet forces to join the CCP regular army was one of the program's main components. ${ }^{8}{ }^{2}$

The Nationalists' query demonstrates the risk of using a "highball" offer in negotiations. A "highball" offer refers to an extraordinarily high opening bid that aims to push the opening offer of the other party closer to or beyond the resistance point. One of the major drawbacks of such a tactic is that the opponent might abandon the negotiations, deeming them a waste of time. ${ }^{83}$

While the KMT negotiators tried to undermine the credibility of the CCP's forty-eight army division opening bid, Mao's twenty-eight division offer, by contrast, instantly made their strident pronouncements seem weak. Mao did not ask Chiang to accept his concession on a quid pro quo basis, but this was not necessary. The timing and size of Mao's concession had automatically pressured Chiang to reciprocate with a sizeable cut of his three-hundred-

81 Qin, 1981-88, series 7, vol. 2, 57, 86-89; Zhonggong Chongqing shiwei dangshi gongzuo weiyuanhui et al., 1984, 196-201, 212-13.

82 Directive, the Secretariat of the CC to regional bureaus, 21 September 1945, in Zhongyang dang'anguan 1989-92, vol. 15, 288-90.

${ }^{8} 3$ Lewicki et al., 2010, 61-69. 
and-fifty-plus army divisions. ${ }^{8}{ }^{4}$ In a worst-case scenario, if Chiang did not respond commensurately, Mao could walk away from the commitment with good reason.

Mao had made a significant concession in one jump. This decisive move imbued him with a moral superiority and allowed him to claim that the twenty-eight division plan was the best and most reasonable final offer: one he must stick to. A moral victory would give Mao an edge over winning "the sympathy of... the middle-of-the-roaders within the country," which was what he had originally planned. ${ }^{85}$ Mao's strategy of using one significant concession to place his party in an unassailable negotiating position was employed by his negotiators against their American counterparts headed by Henry Kissinger in the 1970s. Kissinger soon learnt the lesson from the Chinese that, even though a concession might look significant initially, it actually amounted to less than a string of piecemeal concessions. In his memoirs, Kissinger used the term "pre-emptive concession" to describe this particular negotiation approach he learnt from PRC interlocutors in the 1970s. ${ }^{86}$

At times, negotiators need to shape their own rules for tactical battles. For the Nationalists, the reality was that even a partial decommissioning of Mao's highly flexible armies was a long shot, but if they could entice Mao to deploy some of his elite troops in the guerrilla theatres of operation and let him win the propaganda battle - the CCP had made genuine attempts to reduce its armed forces - a full-scale civil war may be delayed, if not averted. Soon after Mao made the concession, Shao urged Zhou to send the remaining CCP troops outside the government-endorsed quota to open up wasteland and complete

\footnotetext{
${ }^{8} 4$ Guofangbu shizheng bianyiju 1975-84, vol. 2, 171.

${ }^{85}$ Mao 1961A, 49.

${ }^{86}$ Kissinger 1979, 752.
} 
construction projects. ${ }^{87}$ Shao's idea was tantamount to an implicit approval that the CCP could keep its forces as station troops.

Mao's commitment to reconciliation was short-lived, however. He reneged on his offer soon after by sending Zhou to inform Zhang Qun that the number of army divisions he intended to retain was forty-eight, not twenty-eight. ${ }^{8} 8$ In other words, the promise Mao made in his previous meeting with Chiang was nothing but a glitch. Existing civil war records do not provide direct evidence for the reasons behind Mao's abandonment of this commitment, but a usually tight-lipped Wang Ruofei revealed some hints about the answer. Wang told Zhang Qun that the difficulty for them to commit to a more cooperative approach was that they would have a hard time persuading their comrades in Yan'an to accept it. ${ }^{89}$

The withdrawal of commitments is not uncommon in negotiation, but the party who reverses a commitment must plan this carefully. In Mao's case, it was not the retraction of his commitment but the way he and his associates handled the situation that did the damage. Importantly, they did not give Chiang any indication that the conditions under which Mao's commitment applied had changed before calling it off. Neither did they take the time to let the issue die silently, and Mao also failed to send his eloquent deputies to deliver a more prudent restatement (e.g., by establishing more conditions) of his commitment. ${ }^{90}$

${ }^{8}$ Qin 1981-88, series 7, vol. 2, 83; Zhonggong Chongqing shiwei dangshi gongzuo weiyuanhui et al., 1984, 206-11.

${ }^{8}$ CKSD, 17 September 1945, Folder 10, Box 44.

${ }^{8} 9$ Qin 1981-88, series 7, vol. 2, 81.

90 Lewicki et al., 2010, 59-60. 
From Chiang's perspective, Mao lost all credibility when he abandoned his promise. Chiang's diary shows that he was offended by Mao's act. Chiang later noted that he sought punishment of the Chinese communists in a most severe manner. ${ }^{91}$ Chiang's expression, in addition to the overblown anti-communist rhetoric recorded in his diaries during that period, provided a niche for some writers to claim that Chiang had come close to arresting Mao in early October $1945 .^{92}$ Although forgiveness was not the greatest forte of either man, they held at least five more meetings afterward, before Mao departed on October 11. However, either these meetings were mere courtesy calls or both men engaged in discussions without making commitments. ${ }^{93}$

\section{A Night with Ambassador Hurley}

When the level of significance of the Mao-Chiang talks decreased, Zhou went to see Hurley on September 18, 1945, before the latter departed for Washington. Zhou told Hurley that if he was leaving, Mao would like to leave before him. Hurley went to Chiang and swiftly secured Chiang's reassurance regarding Mao's safety in Chongqing. ${ }^{94}$ Although Mao was considering walk-away alternatives, the leverage had just tilted in the CCP's favor. The CCP's intelligence agents had obtained information that Chiang's negotiators had, among other concessions, been prepared to accept a CCP army of sixteen infantry divisions. ${ }^{95}$

\footnotetext{
${ }^{1}$ CKSD, 17 and 27 September 1945, Folder 10, Box 44.

92 Yang 2009, vol. 3, 261-67.

9 з JZZD, vol. 62, 588, vol. 63, 80-81, 86, 112-13.

94 Correspondence, Hurley to Mao, 19 September, in FRUS, 1945, vol. 7, 466.

${ }^{5} \mathrm{Hu} 2003,403$.
} 
Although Zhou was informed of his opponents' next move, he needed to maneuver tactfully in order to gain more from the bargain. Zhou made his move on September 19. He offered to cut five more army divisions and reduce the CCP's demands on local governments. He also pledged to cede eight minor Liberated Areas, mostly in southern and eastern China where their positions were vulnerable to Nationalist attack. According to Zhou, the communist forces from these areas would be redeployed northward from their present positions in roughly two phases. In geographical terms, the CCP would allow the KMT to take control of the territories stretched south from the Lanzhou-Lianyungang Railway in the north, in exchange for Chiang's cooperation in letting the CCP establish a stranglehold on North China. ${ }^{96}$ Zhou's concession complied with a well-conceived negotiation trade-off plan developed by Mao before the negotiations began. ${ }^{97}$

The Nationalists were compelled to reciprocate Zhou's concessions. During the meeting on September 21, Zhang Zhizhong conceded begrudgingly that a CCP army of sixteen divisions was acceptable. Simultaneously, Zhang also proposed to negotiate a final deal on the actual number of the CCP troops, sending a message of "price slashed and still negotiable" to Zhou. Zhang's reciprocal concessions indicated that the give-and-take process was finally underway for both parties. ${ }^{98}$

${ }^{9}$ Qin 1981-88, series 7, vol. 2, 86; Zhonggong Chongqing shiwei dangshi gongzuo weiyuanhui et al., 1984, 212-13.

97 Mao, 1993.

${ }^{9}$ Qin 1981-88, series 7, vol. 2, 89-97; Zhonggong Chongqing shiwei dangshi gongzuo weiyuanhui et al., 1984, 213-18. 
Just when Zhou had the situation well in hand, Wang Roufei lost his temper at this key moment. On one occasion, he described the KMT regime as a "Mussolinian government" and a "Hitlerian government." On another occasion, he simply issued an invitation to war, yelling "In that case, it would be better for the central [government] to annihilate all the armies of our party!" ${ }^{9}$ The timing of Wang's hot-tempered outburst could not possibly have been worse as it occurred when the peace talks had just swung in the CCP's favor. The negotiations were adjourned after Wang's indiscreet remarks. ${ }^{10} 0$ Recounting these events in a public report made in 1946, Shao did not mention Wang's role in the meeting, but stated that the situation was so tense the entire negotiation almost broke down. ${ }^{1} 01$

The tactical use of aggressive behavior is deemed unacceptable by some scholars for ethical reasons, as it may backfire on the aggressor; ratcheted-up calls for war in peace talks are perceived similarly. ${ }^{1} 02$ In Wang's case, he would have preferred to maintain the momentum rather than forcing an adjournment, because his party had already detected the concession pattern of their rivals. In general, if the adversary's concession patterns are detectable, negotiators will normally prolong proceedings to gain an advantage. ${ }^{103}$ Wang, however, chose to let his emotions run wild and the negotiations teetered on the edge of breakdown.

\footnotetext{
${ }^{9}$ Qin 1981-88, series 7, vol. 2, 91, 95; Tong 1994, 374-76.

100 Qin 1981-88, series 7, vol. 2, 89-97.

101 Shao, 1984.

102 Lewicki et al., 2010, 33, 61-69.

${ }^{103}$ Hendon, et al., 2003.
} 
Zhou had no choice but to take the fight to the KMT. He began to spread news about the negotiation deadlock to various interested parties, including the media; ${ }^{104}$ but such an approach ("even the bystanders don't agree with you") ran the risk of further annoying the already angry opponents. ${ }^{105}$ In Yan'an, the CCP leaders, believing that Chiang would use his armies to intimidate them into capitulation, prepared to fight fire with fire. They telegraphed Mao on September 26, requesting him to stop the negotiations and return. ${ }^{106}$ Mao decided to stay, but the negotiations were in shambles. ${ }^{1} 07$

The use of military force was more direct than peace talks. From Chongqing, Mao sent a message to his generals who were at that time battling the KMT forces under Yan Xishan in south-eastern Shanxi over the previously Japanese occupied territories. The localized civil war had started in late August when the leaders of both parties were ready to enter peace talks. In mid-September, the CCP forces gained the upper hand in the combat and placed a large group of KMT troops under siege. ${ }^{108}$ Mao's message stated, “The more battles you win, the safer we are here and the more initiative we have in negotiations." ${ }^{1} 09$ Mao's

104 Zhonggong zhongyang wenxian yanjiushi 1989, 620-21.

105 Zhou's approach would be a variant of the "your own friends don't agree with you" tactic. See Kahn 1964, 190-91.

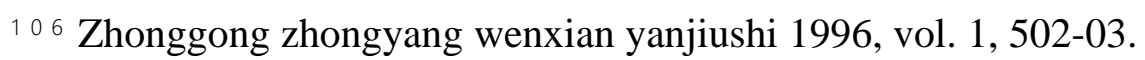

107 Yang 2005, 324.

108 Guofangbu shizheng bianyiju 1975-84, vol. 2, 15-16.

109 Nie 1988, 518. 
generals did as he instructed, and the fighting continued unabated. Nowadays, this "whipsaw" approach is dubbed "Fight, Talk, Fight, Talk."" 110

As the overhyped military confrontations gained momentum and the conciliation atmosphere could no longer be sheltered by the peace talks, Hurley could not continue as a passive peace maker. He decided to intervene and bring the negotiations back on track. He went to see Chiang on the night of September 21, before his departure for Washington. In a negotiation situation, when a party considers making a larger concession, a mediator biased in favor of it has the credibility to convince it that the compromise is necessary and all its losses will be compensated in a favorable final settlement. ${ }^{1{ }^{11}}$ As the US was a key supporter of Chiang's government, Hurley succeeded in persuading Chiang to accept a compromiseextending the upper limit of the CCP armed forces number to twenty army divisions in exchange for the CCP withdrawing its bid for provincial governments in North China. When Hurley brought Chiang's plan to the Chinese communists, Zhang Qun waited for the outcome in a room next to the meeting venue. It turned out to be a long night for Zhang, as Hurley's meeting with the CCP representatives did not end until the next morning. ${ }^{1}{ }^{12}$

Chiang's overwhelming response sent clear messages to both Mao and Hurley. First, while he agreed to make concessions, he did not change his anti-communist stance, and the

\footnotetext{
110 Wilhelm 1994, 131.

111 Kydd 2003, 607; Svensson 2009, 463-64.

112 Cable, Hurley to Byrnes, 23 September, in FRUS, 1945, vol. 7, 466-68;

JZZD, vol. 62, 626; Hu 2003, 406.
} 
CCP could not regard his final offer as a weakness to be exploited. Second, Chiang's trust in his American ally would not be sustained unless Hurley delivered a deal to his satisfaction.

Hurley ventured into a very different bargaining environment in his meeting with the Chinese communists. He did not have the same leverage to influence Mao as with his ally Chiang. Besides, biased mediators may be unable to communicate effectively with the less "friendly" disputant, thereby affecting their mediation approach. ${ }^{13}$ As discussed, a partial peace broker can be a reliable third party for the least favored disputant on some occasions. However, biased mediators can also provide less critical and more up-to-date information to the disputant they are prejudiced against simply because they are allied with the other disputant. ${ }^{114}$ In the CCP's case, Mao might have trusted Hurley to look after his safety in Chongqing, knowing that Chiang was constrained by the US. However, he may not have trusted Hurley to provide reliable information about the negotiation (e.g., Chiang's negotiation bottom line), knowing that the American was motivated to secure a favorable deal for Chiang. While the coexistence of trust and mistrust is not uncommon in negotiations, ${ }^{115}$ both Hurley and Mao needed to manage this paradox when they met.

During his meeting with the Chinese communists, Hurley acknowledged that military and governance arrangements were the two key issues that had not yet been agreed upon; the reason being that both parties were "attempting to settle too many details." 116 According to

\footnotetext{
113 Corbetta and Melin 2018, 2212.

114 Kydd 2003, 607.

${ }^{115}$ Lewicki et al., 2010, 310.

116 Cable, Hurley to Byrnes, 23 September, in FRUS, 1945, vol. 7, 468.
} 
Hurley's own account, he did not do anything that other mediators would not have done under the circumstances. First, he managed the exchange of offers for both parties but let their leaders have the final say. Second, he tried to shift the bargaining situation by urging the two disputants to secure an interim deal on "basic over-all principles" and worked out "the details" in the next stage of the negotiations. ${ }^{117}$ Hurley claimed that Mao accepted his advice: Mao assured him that the peace talks would not break down and that he would not reject Chiang's offer, although his party would like to consider it thoroughly before deciding. ${ }^{118}$

Nevertheless, Mao and his associates were completely dissatisfied with Hurley's approach. A PRC source claims that Hurley put a great deal of pressure on the $\mathrm{CCP}$ negotiators during the meeting. ${ }^{119}$ Hurley is also criticized for ignoring that the core of the disagreements actually originated from those matters he regarded as "the details." ${ }^{2}{ }^{0}$ Mao was irritated. "The American government, Wedemeyer and Hurley treated us very badly," said Mao, venting his frustrations after he returned to Yan'an. ${ }^{12} 1$

117 Cable, Hurley to Byrnes, 23 September, in FRUS, 1945, vol. 7, 468.

118 Hu 2003, 406; cable, Hurley to Byrnes, 23 September 1945, in FRUS, 1945, vol.7, 466-

68.

${ }^{119} \mathrm{Hu} 2003,405$.

120 Hsü 1990, 623.

121 Hu 2003, 406. 
Mao's comment inflamed a deep-set antipathy toward Hurley in some quarters. While Mao’s secretary Hu Qiaomu remembered Hurley’s act as “despicable” (beilie 卑劣), ${ }^{12}$ a recent study describes the American's attitude as “truculent and unreasonable” (manheng 蛮 横) and claims that he “flew into a rage” (shengse juli 声色俱厉) when he attempted to intimidate Mao into submission. ${ }^{123}$ Admittedly, Hurley did not develop a good reputation for being well behaved. He was reportedly short-tempered and rough in his language when he had heated exchanges with a disobedient subordinate, John Paton Davies, a second secretary of the US embassy, in January $1945 .{ }^{124}$ The report seems to support the critics, who offer a damning case against Hurley: the American was desperate to report to the president about the peace talk's progress in a way that looked positive, to obscure the failure of his mission in China. ${ }^{125}$

Criticism of Hurley at the time (from Hu's memoirs) included a hard-hitting broadside against him for ignoring the obvious and arguing the reverse. Knowing that both parties had already come close to issuing a joint communiqué, he threatened that as long as no agreement was reached on the Liberated Areas, no official announcement would be made. According to $\mathrm{Hu}$, Mao talked to Hurley with great forbearance and defended his party's core interests without anger. Consequently, Mao succeeded in stopping Hurley from sabotaging the negotiations. ${ }^{126}$ In the end, however, Mao agreed - under duress - to reduce his troop

\footnotetext{
$122 \mathrm{Hu} 2003,406$.

123 Yang 2005, 323-24.

124 Yu 1996, 190.

125 Yang 2005, 323-24; Hu 2003, 405-6.

${ }^{126} \mathrm{Hu} 2003,406$.
} 
numbers to twenty army divisions. ${ }^{127}$ Hurley was severely criticized for his unfair bias against the $\mathrm{CCP}$.

After a long adjournment, the negotiations resumed on September 27, 1945, in the wake of Hurley's intervention. Both parties started the discussion with some very positive dialogue, but Wang Ruofei was conspicuously quiet throughout the meeting. The two parties quickly moved on to discuss the technicalities of army reorganization and unresolved issues about the CCP's Liberated Areas. ${ }^{128}$ This progress indicates that both parties were ready to settle most of their differences regarding the armed forces numbers, and an agreement was not too far away.

The two parties also made strides toward agreement on political issues. Zhou had proposed a multiparty political consultation peace forum (later the Political Consultative Conference $[\mathrm{PCC}])$ in early September to discuss issues over the political structural reform, including the re-election of all delegates to the KMT-manipulated state legislative body-the National Assembly. ${ }^{129}$ The matter had been discussed for almost a month, and both parties had come very close to striking a deal. While the Nationalists believed that the existing delegates to the National Assembly should be considered valid, with no comprehensive reelection necessary, they agreed to expand the number of delegates in addition to those already elected. After several rounds of negotiations, Zhou showed empathy to the Nationalists'

\footnotetext{
127 Yang 2005, 324.

128 Zhang 1968, 134-37.

129 Qin 1981-88, series 7, vol. 2, 60-67; Zhonggong Chongqing shiwei dangshi gongzuo weiyuanhui et al., 1984, 201.
} 
position on the issues. ${ }^{130}$ In late September, the two parties were able to reach an agreement in principle that the Nationalists would take the necessary steps to convene the PCC. Leaders of the minor parties and non-partisan politicians were also invited to contribute. ${ }^{131}$

The negotiation had an intriguing twist on October 5, 1945. The KMT acknowledged and engaged with the CCP's territorial claims for the first time since the negotiations had begun. As a compromise, Zhang Zhizhong offered to endorse a CCP-nominated administrative inspector (xingzheng ducha 行政督察) to govern joint CCP-held counties. The "inspector" would be sent as a civilian commissioner to the area. ${ }^{132}$ Zhang's proposal shared some key similarities with the one Zhou had proposed in $1939 .{ }^{133}$ The conceptual clarity both parties achieved on the subject from previous negotiations prompted Zhou's instant, albeit partial, approval. Zhou stated that the idea would be useful in northern Jiangsu and Anhui, but was not viable in those provinces already under the CCP's tight control. However, the two parties sought no practical ways to make Zhang's plan work, particularly in those two provinces Zhou deemed most amenable to resolution. ${ }^{134}$ From the CCP's perspective, Zhou

130 "Chinese Ministry of Information to the American Embassy." 3 September, in FRUS, 1945, vol. 7, 459-62; Qin 1981-88, series 7, vol. 2, 73-78.

131 Document, Wu to Robertson, 23 September, in FRUS, 1945, vol. 7, 468-69; Zhang 1968, $138-45$.

132 Zhonggong Chongqing shiwei dangshi gongzuo weiyuanhui et al., 1984, 224-27.

133 Yang 2005, 204-6.

134 Tong 1994, 377; Zhonggong Chongqing shiwei dangshi gongzuo weiyuanhui et al., 1984, 
could not accept Zhang's plan because it would limit the CCP's authority below the provincial level. ${ }^{135}$ At the end of the meeting, Zhou promised to convey Zhang's plan to Mao. ${ }^{136}$ Zhou's statement seemingly indicated to the Nationalists that he did not have the authority to make agreements. This "calculated incompetence" approach would have made negotiations more difficult and therefore lengthier. ${ }^{137}$ At the negotiating table, however, things often take longer than participants expect.

Although the meeting did not resolve the territorial dispute instantly, the Zhang-Zhou exchange of ideas suggests that local solutions to a nationwide problem were possible. The challenge for the two belligerents was that they must find the courage to pick up where they had left off during their anti-Japanese alliance, and activate the "fractioning" approach to manage the prolonged and intractable disputes. Conversely, if the two parties were not ready to accept creative options to resolve their dispute, Zhang's plan would only represent fractured ideas.

Just when the interlocutors of both parties started to consider partial solutions to a series of broad and complicated issues, politicians from both parties urgently needed a result. On October 8, 1945, the two disputants reached consensus on a CCP-drafted summary of the negotiations and consented to a signed agreement. ${ }^{138}$ Zhang Zhizhong's talk with Mao pithily expressed the state of mind of both party leaders. Soon after the agreement was

224-27.

${ }^{13} 5$ Deng 2005, 58.

136 Zhonggong Chongqing shiwei dangshi gongzuo weiyuanhui et al., 1984, 227.

137 Lewicki et al., 2010, 44-45.

138 Yang 2005, 327. 
finalized, he told Mao that "[We] can't afford not to publicize this [agreement], since you came here with great honour, [we] have to produce something." 139 The agreement would be signed on October 10, the National Day of the ROC.

\section{Tragedy at the Eleventh Hour}

While the two belligerent parties tried their best to foster a conciliatory atmosphere before the agreement was signed, an unexpected incident almost derailed their efforts. On October 8, a high-speed hit-and-run traffic incident and subsequent shooting involving a KMT army officer in north-west Chongqing resulted in the death of Zhou's staffer Li Shaoshi. The suspect vehicle was Zhou's official car, but Zhou was not in the car when the fatal incident occurred. The vehicle was fired upon when its driver, who was allegedly a "new" employee of the Eighteenth Group Army office (the CCP's liaison office in Chongqing), failed to stop after it inflicted grave injury on a KMT soldier who was on the side of the road. Li was a passenger in the vehicle, and succumbed to gunshot wounds inflicted by one of the "warning" shots from a KMT army officer trying to stop the rampaging car. The driver mysteriously went missing after the incident. ${ }^{140}$

Adding to the seriousness of the incident was the identity of the shooting victim. Li was the son-in-law of senior KMT left-wing leader Liao Zhongkai. Liao had been assassinated by suspected inner-party rivals in 1925. Li's death therefore sent immediate shock waves across Chongqing, and speculation increased that it was an assassination. ${ }^{141}$ This was a serious and

\footnotetext{
${ }^{139} \mathrm{Hu} 2003,411$.

140 Zheng 1987, 46-47; Li 1987, 92-96.

141 Zheng 1987, 46-47; Li 1987, 92-96.
} 
complicated criminal case because it involved multiple felony offences in addition to the celebrity status of one of the victims' family. To the great chagrin of conspiracy theorists, both parties colluded to minimize the incident. They quickly accepted the result of a rapid KMT investigation to ensure that Li's tragic passing would not hinder successful signing of the agreement. ${ }^{142}$ Although the key person of interest - Zhou's driver-remained at large, a CCP spokesperson swiftly crushed all rumors on October 11, stating that Li's death was a sad accident. ${ }^{143}$ As Hu Qiaomu recalled, the two parties were most concerned about a fiery lastminute breakdown of the negotiations. ${ }^{144}$

On October 10, the two parties signed the "Summary of the conversations between representatives of the [National] Government and of the Chinese Communist Party"-more commonly known as the "Double Tenth Agreement." It did not provide a comprehensive agreement to resolve all disputes between the two parties. Rather, it was an interim accord proposing mechanisms for further negotiations. First, it confirmed that a multiparty peace forum of the PCC would be convened. The PCC would be a multiparty political conference, made up of representatives from the two major parties, minor parties, and non-partisans. It would meet as a consultative body to discuss issues concerning democratization of the government and the nation's military problems. The agreement stated that unresolved issues regarding the convocation of the National Assembly also would be brought before the PCC

\footnotetext{
142 Zheng 1987, 46-47; Li 1987, 92-96; Hu 2003, 412.

143 Zheng 1987, 46-47.

${ }^{144} \mathrm{Hu} 2003$, 407-8.
} 
for settlement. ${ }^{145}$ In other words, the PCC would discuss the unresolved issues where the Chongqing negotiations had left off.

Another critical component of the Double Tenth Agreement was that the CCP would cut its forces to between twenty-four to twenty divisions, pending adoption of a future army nationalization and reorganization program. It also stated that the CCP troops deployed in eight scattered areas would be either demobilized or redeployed to other areas, such as the territory located in the northern area of the Lanzhou-Lianyungang Railway. Notably, the agreement made no mention of the CCP's proposal regarding provincial governments in North China. Nevertheless, the show of readiness to reduce the size of its military and concede territories constituted the most significant $\mathrm{CCP}$ concessions in the treaty. A key clause in the agreement tried to cultivate an open-ended environment for resolving the territorial power-sharing issues, with a declaration that negotiations on the unsettled issues surrounding the Liberated Areas would be continued. ${ }^{146}$

The agreement was signed just after the frenzied fighting in Shanxi ended on October 8 with a CCP victory, which inflicted heavy casualties on the KMT troops. ${ }^{147}$ To counteract the poor impression conveyed by the spectacle of the two belligerent parties fighting in one place while signing a peace deal in another, Nationalist officials alleged that the battle was the result of Yan Xishan's own decision and had nothing to do with the negotiations. ${ }^{148}$ Mao

\footnotetext{
${ }^{145}$ United States Department of State 1967, vol. 2, 577-81.

146 United States Department of State 1967, vol. 2, 577-81.

147 Guofangbu shizheng bianyiju 1975-84, vol. 2, 15-16; Zhongyang dang'anguan 1989-92, vol. $15,342-43$.

${ }^{148}$ Lü 1984.
} 
left immediately after the agreement was signed, but Zhou and Wang Ruofei continued the negotiations with their KMT counterparts.

\section{"Thank God, Amen"}

China's modern history would be barren without the KMT and CCP's waging of war and quest for peace. The two deadly enemies might have had "long-term plans" 149 to eliminate each other, but at the precipice, they cooperated. They formed an alliance against Japanese invasion, although bloody skirmishes continued unabated. The two parties therefore cut their intractable conflicts into smaller segments, to gain short-term or alternative solutions and sustain their weak alliance, thwarting a full-blown civil war. After WWII, the Chongqing negotiations set the stage for interlocutors and mediators to negotiate peaceful cooperation at a time when China was edging toward a more fateful round of infighting.

The reality around the negotiating table in post-war Chongqing was that there were no quick fixes for entrenched disagreements between the two antagonists. It is, then, not surprising that Chiang and Mao started the negotiations with a hard-nosed approach. But once the two paramount leaders played a role in the negotiations, if they did not want to abandon the talks altogether, they had few options except to strive for incremental progress. "No concession indicates a deadlock," 150 and neither man wanted to risk his reputation being besmirched through a stalemate, regardless of their initial intent to enter discussions.

The case of the Chongqing negotiations supports the observation that political actors' “true intention" is a matter of uncertainty. Many factors may influence actors' decision-

\footnotetext{
149 Kan 2000, 100.

150 Hendon et.al, 2003, 80.
} 
making, and decision makers can always change their minds. ${ }^{151}$ This article shows that the interaction dynamics in the negotiations pushed the two belligerent participants to make concessions, even though these were likely to be small pieces of a bigger puzzle and did not guarantee a comprehensive agreement.

Chiang's anti-communist mindset did not stop him from allowing his negotiators to find interim compromises, notwithstanding his initial refusal to engage with the CCP over its territorial power-sharing demands. Mao's talk with Chiang led to a watering down of the proposed division numbers of the CCP army. Mao's twenty-eight division proposal would have been a game changer in the negotiations not only because the actual impact on his forces would be negligible, but also because of the advantage it would gain from propelling Chiang into reciprocating without pushing him to the extreme. In this sense, Mao's revocation of his concession makes an interesting case in history. From a theoretical perspective, Mao must have overvalued the concession he once offered and severely undervalued what he could gain in return, because he recanted his commitment to cut the CCP armies down to twenty-eight divisions even before Chiang could reciprocate. ${ }^{152}$ Mao remains a forerunner of the "preemptive concession" approach employed by the PRC negotiators decades later, which gained recognition from Kissinger.

Kissinger was one of the great American negotiators in the 1970s. His sound appreciation of the idea Mao had once advocated back in 1945 was just one example showing the legacy of the Chongqing negotiations is more significant than previously acknowledged. The Mao-Chiang summit was part of a failed peace, as previously mentioned, but any

\footnotetext{
151 Wendt 1999, 107.

152 Levy 1996, 187.
} 
negotiation can lose momentum, reach a deadlock and collapse in the worst possible way. Nevertheless, the principles, verbal commitments and even the smallest area of common ground agreed upon or discussed may help set the foundation for future negotiations, irrespective of the outcome of the current one. The experiences showcased in the Chongqing negotiations, such as making concessions and pushing for a deal, the difficulties in overcoming impasses in territorial power-sharing disputes and managing the dilemma of biased mediators, have become an integrated and shared knowledge for the many negotiators that followed. This explains why PRC interlocutors found it imperative to access archival negotiation records in preparation for meetings with their Western counterparts after 1949. ${ }^{153}$ A contemporary mind is pivotal to our understanding of these negotiation records, as this article has demonstrated. Mao botched his withdrawal of commitments in his highlevel talks with Chiang, but he and Kissinger would have agreed that it is often the failed person who is the pioneer in new undertakings.

Many famous negotiators in history have been controversial, and Hurley was perhaps a leader of this class. The major interest of this article, however, is his approach to negotiation, not his personality. During the Chongqing peace talks, Hurley intervened when the negotiations veered off track. As a third-party mediator, he encouraged both parties to stay on, accept an interim deal, and strive for breakthroughs via multiple negotiations in the hope that an all-out war could be avoided. That was basically the approach that Mao meekly agreed to in a media interview. ${ }^{154}$ Hurley was criticized by some for being too passive ${ }^{155}$

\footnotetext{
153 Wilhelm 1994, 43-44.

154 Zhonggong Chongqing shiwei dangshi gongzuo weiyuanhui et al., 1984, 105.

${ }^{15}$ Hsü 1990, 622-23.
} 
and by others for being too opportunist. ${ }^{156}$ These assessments seem to encapsulate Hurley's problems. The American was aware from the beginning that although he had the power to induce his ally Chiang to make concessions, a hardline anti-communist like Chiang would make concessions only out of expediency. As he could only persuade Chiang of the expediency of a peace deal with the CCP, Chiang's trust in him was highly conditional. To broker a deal, Hurley also needed to exert strong and consistent pressure on his CCP clients, but the US government did not have the necessary means to apply such pressure effectively. ${ }^{157}$ When Hurley did that, his use of high-pressure tactics ran the risk of infuriating Mao, notwithstanding that mediator pressure on disputants has been recognized as a useful way to resolve conflicts. ${ }^{158}$ Hurley's predicament explains the reason mediators often prefer incremental progress, ${ }^{159}$ and to identify opportunity in every difficulty.

Hurley has been scrutinized, particularly for his meeting with Mao. On the basis of existing historical evidence, Hurley exerted third-party coercion when he talked to Mao. Whether Hurley overstepped his authority as a mediator will continue to be controversial. While Hurley, Mao, and even Chiang struggled to manage the trust/distrust paradox in their relationships, the reality was that Mao relied on Hurley for his personal security in attending the peace conference. When the negotiations hit a deadlock, he reaped the benefits of the powerful but biased American mediator in forcing Chiang to make a concession- a daunting task he was unlikely to accomplish alone.

\footnotetext{
$15{ }^{6}$ Niu 1993, 143.

157 Vicent to Hurley, 2 April, in FRUS, 1945, vol. 7, 323-25.

158 Zagare and Kilgour, 2003.

159 Wise 2018, 4, 32.
} 
Mao, like Chiang, was impelled by Hurley to agree on a preliminary resolution of reducing the $\mathrm{CCP}$ armed forces to twenty army divisions, willingly or unwillingly. This figure was certainly lower than the twenty-eight division plan Mao initially proposed and ultimately chose to retract, but it allowed Mao to put a positive spin on his peace efforts. "Kuomintang propaganda has been saying that the Communist Party is just scrambling for guns. But we have said we are ready to make concessions," Mao declared, on a high note. ${ }^{160}$

When the negotiations approached closure and leaders of both parties were pursuing military solutions, negotiators sought partial solutions to their unresolved territorial conflicts. Zhang Zhizhong's “administrative inspector" solution was a thoughtful move in the way that it acknowledged the territorial claims of his opponent via a creative repurposing of his opponent's old idea. Zhou did not give Zhang's plan his full support, but their exchange of ideas confirmed the availability of peaceful alternatives. Wang's emotional outburst and Zhou's use of calculated incompetence, however, shows that the emotional toll was probably too high for the parties to put their bloody past behind them and consider creative peaceful alternatives in the given time frame. To paraphrase Geoffrey Blainey, if the two parties rejected these alternatives, one can only assume that they preferred war. ${ }^{161}$

The Double Tenth Agreement merely promoted an open-ended environment for further negotiations on territorial power-sharing disputes. Some scholars have been clearly disappointed by this. For example, Pepper characterizes the treatment of the communist Liberated Areas question in the agreement as "a key issue on which not even superficial

\footnotetext{
160 Mao 1961C, 57.

161 Blainey 1973, 159.
} 
agreement could be reached." ${ }^{162}$ Negotiations could not remain open-ended forever; nevertheless, territorial disputes are often too messy to be resolved immediately. Elements of open-endedness in agreements give disputants and mediators breathing space to manage their competing interests cumulatively. ${ }^{163}$ Given that Chiang's and Mao's troops were still engaged in battle when the agreement was about to be signed, formalizing the unsettled Liberated Areas problem in the accord seems to have been more practical than pursuing an early settlement.

The peace talks stumbled into their second phase on October 20, 1945, further complicated by the rapidly deteriorating military situation in North China. War is commonly launched by politicians in order to serve their political goals; but once a war has commenced, the nature of war serves itself, and its initiators can struggle to manage it. ${ }^{164}$ China's military situation in late 1945 seems to confirm this view. The two parties failed to break the deadlock over military issues through negotiation. The Nationalists insisted on government troop movements into Japanese-occupied territories, but the Chinese communists saw this as an invasion of their territories. The KMT called for an immediate withdrawal of all CCP troops from the lines of communication, but CCP representatives bluntly rejected this. ${ }^{165}$ Both parties soon reached stalemate in their negotiations. ${ }^{166}$ Zhou flew back to Yan'an on

\footnotetext{
162 Pepper 1986, 724.

163 Wise 2018, 25, 34, 37.

164 Gray 2002, 15.

165 Anon. 1981, 454-55; JZZD, vol. 63, 358-59. Cf., Yang 2005, 337-38.

${ }^{16}{ }^{6}$ Cable, Robertson to Byrnes, 4 November, in FRUS, 1945, vol. 7, 601-2.
} 
November $25,{ }^{167}$ but he told the Americans that he would be back when the PCC was convened. ${ }^{168}$

Back in Yan'an, Mao delivered a report about the negotiations to the cadres. His private talks with Chiang were not mentioned. Rather, Mao emphasized their recent military victory in Shanxi, the combat readiness of the Liberated Areas and communism's rise in a global context. Mao noted the concessions they had made in the final agreement, but for him, these were designed to "frustrate the Kuomintang's plot for civil war." ${ }^{169}$ Mao spared no effort to ramp up the war-like rhetoric. "[I]f they [the KMT] attack and we wipe them out, they will have satisfaction; wipe out some, some satisfaction; wipe out more, more satisfaction; wipe out the whole lot, complete satisfaction," he asserted. ${ }^{170}$ The blood-drenched battlefield soon proved that Mao's patter was no joke. Chiang, on the other hand, had maintained his personal antipathy toward Mao at a peak since the negotiations began. He could not hide his joy after learning that Mao had received an angry lecture from Wedemeyer over the involvement of CCP troops in the murder of the US intelligence officer John Birch. ${ }^{171}$ "Thank God, amen," Chiang noted. ${ }^{172}$

\footnotetext{
167 Zhonggong zhongyang wenxian yanjiushi 1989, 627.

168 Memorandum of conversation by Melby, 13 November, in FRUS, 1945, vol. 7, 624-25.

${ }^{169}$ Mao 1961C, 56.

170 Mao 1961C, 56.

171 Yu 1996, 235-41.

172 JZZD, vol. 62, 407-8. The current photocopied edition of JZZD clearly shows that there were manual blackouts against the six Chinese characters of "thank God, amen" (ganxie
} 


\section{References}

Archival Materials

CKSD Chiang Kai-shek Diaries. Hoover Institution Archives, Stanford University, Stanford, California.

Jiang Zhongzheng zongtong wenwu 蒋中正总统文物 [Materials of President Chiang Kaishek], 22 August 1945. 002-020300-00027-038, Guoshiguan (Academia Historica), Taipei.

Other Primarily Sources

Anon. 1981. Tingzhan tanpan ziliao 停战谈判资料 [Source Materials on Cease-fire Negotiations]. Chengdu: Sichuan renmin chubanshe.

FRUS United States Department of State. 1861-1996. Foreign Relations of the United States: Diplomatic Papers. Washington, DC: United States Government Printing Office.

Hu Qiaomu 胡乔木. 2003. Hu Qiaomu huiyi Mao Zedong 胡乔木回忆毛泽东 [Hu Qiaomu Remembers Mao Zedong], revised and enlarged edition. Beijing: Renmin chubanshe. Jiang Yuntian 蒋匀田. 1976. Zhongguo jindaishi zhuanliedian 中国近代史转捩点 [The Turning Point of Modern Chinese History]. Hong Kong: Youlian chubanshe.

shangdi amen 感謝上帝阿門), but the blackout was still very readable. For further reference, see CKSD, 31 August 1945, Folder 9, Box 44. 
Jervis, Robert. 1989. The Meaning of the Nuclear Revolution: Statecraft and the Prospect of Armageddon. Ithaca, NY: Cornell University Press.

JZZD Jiang Zhongzheng zongtong dang'an: Shilüe gaoben 蒋中正总统档案: 事略稿本 [The Chiang Kai-shek Collections: The Chronological Events]. 2011-2012. vols. 6263. Taipei: Guoshiguan.

Kissinger, Henry. 1979. White House Years. Boston: Little Brown.

Li Jiexin 李介新. 1987. “Guomindang xianbing silingbu pai zhu Guiyuan jingwei ban de huiyi” 国民党宪兵司令部派驻桂圆警卫班的回忆 [My Recollections as a Member of the Security Squad at the Cinnamon Garden]. In Zhongguo renmin zhengzhi xieshang huiyi Sichuan sheng Chongqing shi weiyuanhui wenshi ziliao yanjiu weiyuanhui 1987, vol. 1, 83-99.

Liu Gangfu 刘刚夫. 1986. “Huiyi wo he Gao Jingting tanpan dacheng xieyi de jingguo” 回忆 我和高敬亭谈判达成协议的经过 [An Account of My Experiences in Negotiating and Reaching an Agreement with Gao Jingting]. In Zhengxie Anhui sheng weiyuanhui wenshi ziliao yanjiu weiyuanhui 政协安徽省委员会文史资料研究委员 会 and Anhui sheng shehui kexueyuan lishi yanjiusuo 安徽省社会科学院历史研究 所 eds. 1986. Anhui wenshi ziliao 安徽文史资料 [Literary-historical Source Materials of Anhui]. Hefei: Anhui renmin chubanshe, vol. 25, 17-30.

Lü Guangguang 吕光光. 1984. “Mao zhuxi tong Zhang Lan de huijian” 毛主席同张澜的会 见 [Chairman Mao’s Meetings with Zhang Lan]. In Zhonggong Chongqing shiwei dangshi gongzuo weiyuanhui et al., 1984, 438-45. 
Mao Zedong. 1961A. “On Peace Negotiation with the Kuomintang-Circular of the Central Committee of the Communist Party of China.” August 26, 1945. In Mao, Selected Works of Mao Tse-Tung, vol. 4, 47-51.

. 1961B. "Situation and Our Policy after Victory over Japan.” August 13, 1945. In Mao, Selected Works of Mao Tse-Tung, vol. 4, 11-26.

—.1961C. “On the Chungking Negotiations.” October 17, 1945. In Mao, Selected Works of Mao Tse-Tung, vol. 4, 53-63.

_. 1961. Selected Works of Mao Tse-Tung, vol. 4. Beijing: Foreign Languages Press. . 1993. “Fu Chongqing tanpan qian zai Zhengzhiju huiyi shang de jianghua”赴重庆 谈判前在政治局会议上的讲话 [Speech Delivered at the Politburo Meeting before Departing for Chongqing], in Zhonggong zhongyang wenxian yanjiushi 中共中央文献 研究室 ed. 1993. Mao Zedong wenji 毛泽东文集 [Collected Works of Mao Zedong]. Beijing: Renmin chubanshe, 1993, vol. 4, 15-17.

Nie Rongzhen (trans. Zhong Renyi). 1988. Inside the Red Star: The Memoirs of Marshal Nie Rongzhen. Beijing: New World Press.

Qin Xiaoyi 秦孝仪 ed. 1981-88. Zhonghua minguo zhongyao shiliao chubian-Dui ri kangzhan shiqi 中华民国重要史料初编一对日抗战时期 [A First Selection of Important Historical Materials of the Republic of China: The War of Resistance against Japan]. Taipei: Zhongguo Guomindang zhongyang weiyuanhui dangshi weiyuanhui.

Shao Lizi 邵力子. 1984. “Zhengfu yu Zhonggong daibiao huitan jingguo” 政府与中共代表 会谈经过 [An Account of the Meetings between the Government and the 
Representatives of the CCP]. January 12, 1946. In Zhonggong Chongqing shiwei dangshi gongzuo weiyuanhui et al., 1984, 357-62.

Shi Peimei 石佩玫 and Zhen Zaiming 甄载明, “Deng Baoshan zai Yulin he Zhonggong tuanjie kangri de pianduan” 邓宝珊在榆林和中共团结抗日的片断 [A Page in the History of Deng Baoshan's Anti-Japanese Alliance with the CCP in Yulin]. In Zhongguo renmin zhengzhi xieshang huiyi Gansu sheng weiyuanhui wenshi ziliao yanjiu weiyuanhui 中国人民政治协商会议甘肃省委员会文史资料研究委员会 ed. 1987 Ganshu wenshi ziliao xuanji 甘肃文史资料选辑 [A Selection of Literaryhistorical Source Materials of Gansu]. Lanzhou: Gansu renmin chubanshe, vol. 25, 112-19.

Tong Xiaopeng 童小鹏. 1994. Fengyu sishi nian 风雨四十年 [A Forty-year Tribulation]. Beijing: Zhongyang wenxian chubanshe.

United States Department of State. 1967. The China White Paper, August 1949. Stanford, CA: Stanford University Press.

Wang Shijie 王世杰. 1990. Wang Shijie riji 王世杰日记 [The Diary of Wang Shijie], vol. 5. Taipei: Academia Sinica.

Wedemeyer, Albert C. 1958. Wedemeyer Reports. New York: Holt.

Xiao Jinguang 萧劲光. 1987. Xiao Jinguang huiyi lu 萧劲光回忆录 [The Memoirs of Xiao Jinguang]. Beijing: Jiefangjun chubanshe.

Xinhua ribao 新华日报 [Xinhua Daily]. 1945. Chongqing. 
Zhang Jiuru 张九如. 1968. Hetan fuzhe zai Zhongguo 和谈覆辙在中国 [The Disastrous Road toward Peace Talks in China]. Taipei: n.p.

Zheng Hong 郑洪. 1987. “Chongqing tanpan jilüe” 重庆谈判纪略 [A Summary of the Chongqing Negotiations]. In Zhongguo renmin zhengzhi xieshang huiyi Sichuan sheng Chongqing shi weiyuanhui wenshi ziliao yanjiu weiyuanhui 1987, vol. 1, 1-56.

Zhonggong Chongqing shiwei dangshi gongzuo weiyuanhui 中共重庆市委党史工作委员会, Chongqing shi zhengxie wenshi ziliao yanjiu weiyuanhui 重庆市政协文史资料研究 委员会 and Hongyan geming jinian guan 红岩革命纪念馆 eds. 1984. Chongqing tanpan jishi 重庆谈判纪实 [The Truth Story of Chongqing Negotiations]. Chongqing: Chongqing chubanshe.

Zhonggong Kaifeng shiwei dangwei bangongshi 中共开封市委党委办公室 and Zhonggong Shangqiu diwei dangwei bangongshi 中共商丘地委党史办公室 eds. 1988. Yudong zhanyi 豫东战役 [The Eastern Henan Campaign]. Zhengzhou: Henan renmin chubanshe.

Zhonggong zhongyang wenxian yanjiushi 中共中央文献研究室 ed. 1989. Zhou Enlai nianpu, 1898-1949 周恩来年谱, 一八九八一一九四九 [Chronological Biography of Zhou Enlai, 1898-1949]. Beijing: Zhongyang wenxian chubanshe. ed. 1993. Mao Zedong nianpu 1893-1949 毛泽东年谱, 一八九三一一九四九 [Chronological Biography of Mao Zedong, 1893-1949]. Beijing: Renmin and Zhongyang wenxian chubanshe. 
ed. 1996. Liu Shaoqi nianpu, 1898-1969 刘少奇年谱, 一八九八一一九六九

[Chronological Biography of Liu Shaoqi, 1898-1969]. Beijing: Zhongyang wenxian chubanshe.

ed. 2006. Zhu De nianpu, xinbian ben, 1886-1976 朱德年谱 (新编本), 一八八六一

一九七六 [Chronological Biography of Zhu De, New Edition, 1886-1976]. Beijing:

Zhongyang wenxian chubanshe.

and Zhongguo renmin jiefangjun junshi kexue yuan 中共人民解放军军事科学院,

eds. 1993. Mao Zedong junshi wenji 毛泽东军事文集 [Collected Military Papers of

Mao Zedong]. Beijing: Junshi kexue chubanshe, Zongyang wenxian chubanshe.

Zhongguo renmin zhengzhi xieshang huiyi Sichuan sheng Chongqing shi weiyuanhui wenshi ziliao yanjiu weiyuanhui 中国人民政治协商会议四川省重庆市委员会文史资料研 究委员会, ed. 1987. Chongqing wenshi ziliao xuanji 重庆文史资料选辑 [A

Selection of Literary-historical Source Materials of Chongqing], vol. 1. Chongqing: n.p.

Zhongyang dang'anguan 中央档案馆, ed. 1989-92. Zhonggong zhongyang wenjian xuanji 中 共中央文件选集 [Selected Documents of the Central Committee of the CCP]. Beijing: Zhongyang dangxiao chubanshe.

Zhongyang ribao 中央日报 [Central Daily News]. 1945. Chengdu.

Zhou Enlai 周恩来. 1996. “Guanyu Guogong tanpan” 关于国共谈判 [On KMT-CCP Peace Talks]. December 5, 1945. In Zhonggong zhongyang wenxian yanjiushi 中共中央文 献研究室 and Zhonggong Nanjingshi weiyuanhui 中共南京市委员会 eds. Zhou 
Enlai yijiusiliu nian tanpan wenxuan 周恩来一九四六年谈判文选 [Selected Essays of Zhou Enlai in the Peace Negotiations of 1946]. Beijing: Zhongyang wenxian chubanshe, 1996, 1-16.

\section{Secondary Sources}

Benton, Gregor. 1999. New Fourth Army: Communist Resistance along the Yangtze and the Huai, 1938-1941. Berkeley, CA: University of California Press.

Bingley, Richard. 2015. The Security Consultant's Handbook. Ely, Cambridgeshire: IT Governance Publishing.

Blainey, Geoffrey. 1973. The Causes of War. New York: Free Press.

Chang, Jung and Jon Halliday. 2005. Mao: The Unknown Story. London: Jonathan Cape.

Chen Zhiling 陈志凌 and He Yang 贺扬. 1986. Wang Ruofei zhuan 王若飞传 [Wang Ruofei Biography]. Shanghai: Shanghai renmin chubanshe.

Cheng, Victor Shiu Chiang. 2005. “Imagining China's Madrid in Manchuria: The Communist Military Strategy at the Onset of the Chinese Civil War, 1945-1946.” Modern China 31.1 (January 2005), 72-114.

Clubb, Edmund O. 1972. Twentieth Century China. 2nd ed. New York: Columbia University Press.

Corbetta, Renato and Molly M. Melin. 2018. "Exploring the Threshold between Conflict Management and Joining in Biased Interventions." Journal of Conflict Resolution 62.10 (November 2018), 2205-31. 
Deng Ye 邓野. 2005. “Lun Guogong Chongqing tanpan de zhengzhi xingzhi” 论国共重庆谈 判的政治性质 [On the Political Nature of the Chongqing Negotiations between the KMT and the CCP]. Jindaishi yanjiu 近代史研究 1 (2005), 30-64.

. 2006. "A New Exploration into the Background and Basic Themes of the Chongqing Negotiations.” Social Sciences in China 2 (2006), 115-27.

Fisher, Roger. 1964. “Fractionating Conflict.” Daedalus 93. 3 (Summer 1964), 920-41.

Guofangbu shizheng bianyiju 国防部史政编译局, ed. 1975-84. Kanluan zhanshi 勘乱战史 [A History of Rebellion Suppression]. Taipei: Guofangbu shizheng bianyiju.

Heinzig, Dieter. 2004. Soviet Union and Communist China, 1945-1950: The Arduous Road to the Alliance. Armonk, NY: M.E. Sharpe.

Gray, Colin S. 2002. Defining and Achieving Decisive Victory. Carlisle, PA: Strategic Studies Institute, US Army War College.

Hendon, Donald W., Matthew H. Roy and Zafar U. Ahmed. 2003. "Negotiation Concession Patterns: A Multi-country, Multi-period Study.” American Business Review, 21.1 (January 2003), 75-83.

Hsü, Immanuel C.Y. 1990. The Rise of Modern China, fourth edition. Oxford: Oxford University Press.

Kahn, Herman. 1964. Thinking about the Unthinkable. New York: Avon Books.

Kan, Francis Yi-hua. 2000. “The Irreconcilable Chinese Rival Regimes and the Weakening of the Policies of Neutrality of the Great Powers." Civil War 3.4 (Winter 2000), 85104. 
Kydd, Andrew. 2003. "Which Side are You On? Bias, Credibility, and Mediation." American Journal of Political Science 47.2 (October 2003), 597-611.

Niu Jun 牛军. 1993. Neizhan qianxi: Meiguo tiaochu Guogong maodun shimo 内战前夕一 美国调处国共矛盾始末 [At the Eve of the Civil War: An Account of the United States' Role in Mediating the KMT-CCP Conflicts]. Taipei: Babilun chubanshe.

Lai, Sherman Xiaogang. 2011. A Springboard to Victory: Shandong Province and Chinese Communist Military and Financial Strength, 1937-1945. Leiden: Brill.

Levy, Jack S. 1996. "Loss Aversion, Framing and Bargaining: The Implications of Prospect Theory for International Conflict.” International Political Science Review 17.2 (April 1996), 179-95.

Lew, Christopher R. 2009. The Third Chinese Revolutionary Civil War, 1945-49: An Analysis of Communist Strategy and Leadership. New York: Routledge.

Lewicki, Roy J., Bruce Barry and David M. Saunders. 2010. Negotiation, sixth edition. New York: McGraw-Hill.

Pepper, Suzanne. 1986. “The KMT-CCP Conflict 1945-1949.” In John K. Fairbank and Albert Feuerwerker, eds. The Cambridge History of China. Cambridge: Cambridge University Press, 1986, Vol.13, part 2, 723-88.

Sheng, Michael M. 1997. Battling Western Imperialism: Mao, Stalin, and the United States. Princeton, NJ: Princeton University Press.

Svensson, Isak. 2009. "Who Brings Which Peace? Neutral Versus Biased Mediation and Institutional Peace Arrangements in Civil Wars.” Journal of Conflict Resolution 53.3 (June 2009), 446-69. 
Tanner, Harold M. 2013. The Battle for Manchuria and the Fate of China: Spring, 1946. Bloomington, IN: Indiana University Press. 2015. Where Chiang Kai-shek Lost China: The Liao-Shen Campaign, 1948. Bloomington, IN: Indiana University Press.

United States Department of the Army. 2009. US Army Guerrilla Warfare Handbook. New York: Skyhorse.

Tsou, Tang. 1963. America's Failure in China, 1941-50. Chicago: University of Chicago Press.

Philips, Tom. "Leaders of China and Taiwan Meet for First Time in Nearly Seven Decades," The Guardian, November 7, 2015, access February 2, 2020. https://www.theguardian.com/world/2015/nov/07/chinas-xi-jinping-and-taiwans-maying-jeou-shake-hands-in-historic-meeting.

Van de Ven, Hans. 2017. China at War: Triumph and Tragedy in the Emergence of the New China, 1937-1952. London: Profile Books.

Wang Chaoguang 汪朝光. 2002. “Zhan yu he de bianzou: Chongqing tanpan zhi Zhengxie huiyi qijian de Zhongguo shiju yanbian”战与和的变奏一重庆谈判至政协会议期间 的中国时局演变 [A Variation on War and Peace: The Evolution of China's Political Situation from the Chongqing negotiations to the Political Consultative Conference]. Jindaishi yanjiu 近代史研究 1 (2002), 14-42. 
Wang Wuzi 王武子 and Tu Wenxue 涂文学 eds. 2002. Yingxiang Zhongguo lishi de yibaige shunjian 影响中国历史的一百个瞬间 [The One Hundred Most Important Moments in Chinese history]. Wuhan: Changjiang wenyi chubanshe.

Wei, William. 1985. Counterrevolution in China: The Nationalists in Jiangxi during the Soviet Period. Ann Arbor: University of Michigan Press.

Wendt, Alexander. 1999. Social Theory of International Politics. Cambridge: Cambridge University Press.

White, Theodore H. and Annalee Jacoby. 1961. Thunder Out of China, 2nd edition. New York: William Sloane.

Wilhelm, Alfred D. 1994. The Chinese at the Negotiating Table: Style and Characteristics. Washington, DC: National Defense University Press.

Wise, Laura. 2018. “Territorial Power-sharing and Inclusion in Peace Processes (PA-X Report, Power-sharing Series).” Edinburgh: Global Justice Academy, University of Edinburgh, 2018, access February 2, 2020.

https://www.politicalsettlements.org/publications-database/territorial-power-sharingand-inclusion-in-peace-processes/

Wu, Tien-wei. 1992. “The Chinese Communist Movement.” In James C. Hsiung and Steven I. Levine, eds. China's Bitter Victory: The War with Japan, 1937-1945. Armonk, NY: M.E. Sharpe, 1992, 79-106.

Yang Kuisong 杨奎松. 1992. Shiqu de jihui? Kangzhan qianhou Guogong tanpan shilu 失去 的机会? 一抗战前后国共谈判实录 [Lost Opportunity? A True Record of the 
KMT-CCP Negotiations during the Period before and after the War of Resistance]. Guilin: Guangxi shifan daxue chubanshe.

Yang Shengqing 杨圣清 ed. 2005. Zhongguo gongchandang tanpanshi 中国共产党谈判史 [A History of Negotiations of the Chinese Communist Party]. Beijing: Zhongyang wenxian chubanshe.

Yang Tianshi 杨天石. 2009. Jiang Jieshi zhenxiang 蒋介石真相 [The Truth about Chiang Kai-shek]. Taipei: Fengyun shidai.

Yu, Maochun. 1996. OSS in China: Prelude to Cold War. New Haven, CT: Yale University Press.

Zagare, Frank C., and D. Marc Kilgour. 2003. “Alignment Patterns, Crisis Bargaining, and Extended Deterrence: A Game-theoretic Analysis.” International Studies Quarterly, 47.4 (December 2003), 587-615. 